\title{
ANALISIS EFEKTIVITAS PENERIMAAN PAJAK DAERAH SERTA KONTRIBUSINYA TERHADAP BELANJA DAERAH (Studi Kasus Pemerintah Provinsi DKI JAKARTA Tahun 2011-2014)
}

\author{
Wimona Angela Nathania, Budi Kurniawan \\ Departemen Akuntansi, Universitas Bunda Mulia, Jakarta, 14430 \\ Email: monaboge@yahoo.com, budikh@hotmail.com
}

\begin{abstract}
Abstrak
Pendapatan Asli Daerah (PAD) merupakan sumber keuangan daerah dan pembiayaan pemerintah. Salah satu penerimaan PAD berasal dari Pajak Daerah, penerimaan dari pajak ini digunakan untuk pembiayaan penyelenggaraan pemerintah dan pembangunan daerah. Pemerintah daerah yang menerima kewenangan ini dituntut masyarakat untuk mempertanggungjawabkan pelaksanaan anggaran belanja.

Untuk mengukur kinerja keuangan pemerintah, dilakukan analisis rasio keuangan sebagai tolak ukur efektivitas dalam realisasi pendapatan dan belanja daerah. Penelitian ini tergolong ke dalam jenis penelitian deskriptif dengan menggunakan data sekunder yang dikumpulkan dengan teknik dokumentasi. Penelitian ini ditujukan untuk mengetahui besarnya tingkat efektivitas penerimaan pajak daerah, mengetahui pengaruh pajak daerah terhadap belanja daerah di Provinsi DKI Jakarta dan kinerja keuangan pemerintah daerah. Hasil penelitian ini diketahui bahwa penerimaan pajak daerah cukup efektif dan keterkaitan dengan belanja daerah pada pemerintahan daerah kota di Jakarta tahun 2011-2014.
\end{abstract}

Kata kunci: Efektivitas, Konstribusi, Pajak Daerah, Anggaran Pendapatan Belanja Daerah, Kinerja Keuangan

\section{Pendahuluan}

Penerimaan pajak memberikan konstribusi yang cukup signifikan, yaitu hampir $70 \%$ terhadap anggaran pendapatan belanja negara bagi pemerintahan kita, dalam kurung waktu selama ini pajak menjadi primadona bagi kelanjutan pembangunan pemerintah Indonesia (Sugianto 2008:1)

Dari tahun ke tahun data jumlah wajib pajak daerah yang dipungut oleh Dinas Pelayanan Pajak Pusat Abdul Muis terus meningkat. Dari tahun 2011 hingga 2014 peningkatan wajib pajak di Jakarta berkembang sebesar 15,50\%. Sedangkan data mengenai penerimaan pajak daerah di Provinsi DKI Jakarta \% Pencapaian 2011 (109,00\%), 2012 (107,24\%), 2013 (103,31\%), dan 2014 (83,40\%). Dari data tersebut diketahui target dan realisasi penerimaan pajak daerah untuk tahun 2011 sampai tahun 2014 terus meningkat, namun realisasi penerimaan pajak tersebut tidak seimbang dengan target yang telah ditentukan. Meskipun penerimaan terus meningkat namun bahwa setiap tahun presentase pencapaian penerimaan pajak daerah Provinsi DKI Jakarta mengalami penurunan.

Penelitian ini bertujuan untuk mengetahui tingkat efektivitas pemungutan pajak daerah, kontribusinya terhadap belanja daerah dan menilai kemandirian keuangan pemerintah provinsi khususnya Provinsi DKI Jakarta yang secara stabil mengalami peningkatan jumlah wajib pajak sebesar $15,50 \%$ dari tahun 2011 2014.

Menurut Undang Peraturan Daerah Nomor 6 Tahun 2010 tentang Ketentuan Umum Pajak Daerah, pajak daerah yang selanjutnya disebut pajak adalah kontribusi wajib kepada daerah yang terutang oleh orang pribadi atau badan yang bersifat memaksa bedasarkan undang undang, dengan tidak mendapatkan imbalan secara langsung dan digunakan untuk 
keperluan daerah bagi kemakmuran rakyat. Menurut Sumenge (2013) yang ditulis dalam jurnalnya, kriteria tingkat efektivitas anggaran belanja sebagai berikut : (1) Jika hasil perbandingan lebih dari $100 \%$, maka anggaran belanja dikatakan sangat efektif. (2) Jika hasil pencapaian antara 90\% - 100\%, maka anggaran belanja dikatakan efektif. (3) Jika hasil pencapaian antara $80 \%$ - 90\%, maka anggaran belanja dikatakan cukup efektif. (4) Jika hasil pencapaian antara $60 \%-80 \%$, maka anggaran belanja dikatakan kurang efektif. Dan (4) Jika hasil pencapaian dibawah $60 \%$, maka anggaran belanja dikatakan tidak efektif.

Menurut Memah (2013) rumus analisis perhitungan kontribusi yang digunakan ialah

Analisis Kontribusi Pajak Daerah

$$
=\frac{\text { Realisasi Pajak Daerah }}{\text { Realisasi Belanja Daerah }} \times 100 \%
$$

Rumus Perhitungan Efektivitas Penerimaan Pajak Daerah menurut Memah (2013):

Analisis Efektivitas Pajak =

$\frac{\text { Realisasi Pajak Daerah }}{\text { Target Pajak Daerah }} \times 100 \%$

Rumus Perbandingan Pajak Daerah dengan Pendapatan Asli Daerah :

Rasio Pajak Daerah terhadap PAD =
$\frac{\text { Realisasi Pajak Darrah }}{P A D} \times 100 \%$

\section{Pembahasan}

Studi terdahulu seperti yang dilakukan oleh Pauwah, Saerang,dan Mandey (2014) menyatakan bahwa rata-rata realisasi PAD cukup efektif dengan disertai pengendalian yang memadai. Memah (2013) juga menyatakan secara keseluruhan kontribusi pajak hotel dan pajak restoran memberikan kontribusi yang baik terhadap PAD. Meskipun menurun Santosa, Tinangon, dan Elim (2014) beberapa rasio efektivitas masih dinyatakan rendah karena masih kurangnya usaha Wajib pajak dalam memenuhi kewajiban perpajakannya.

Dalam penelitian ini metode analisis data yang peneliti terapkan adalah metode deskriptif kualitatif dengan data sekunder yang telah diperoleh dari Dinas Pelayanan Pajak Pusat dan Badan Pengelola Keuangan dan Aset Daerah

Analisis efektivitas penerimaan pajak daerah yaitu analisis yang menggambarkan kemampuan pemerintah daerah dalam merealisasikan pajak daerah yang direncanakan dibandingkan dengan target yang ditetapkan (Halim, 2004).

Rumus Perhitungan Efektivitas Halim (2004) :

$$
\begin{aligned}
& \text { Analisis Efektivitas Pajak } \\
& =\frac{\text { Realisasi Pajak Daerah }}{\text { Target Pajak Daerah }} \times 100 \%
\end{aligned}
$$

Analisis efektivitas pajak daerah adalah analisis yang menggambarkan kemampuan pemerintah dalam merealisasikan pajak daerah yang didapat dibandingkan dengan anggaran yang ditetapkan bedasarkan potensi riil daerah (Halim, 2004:135).

Tabel 1. EFEKTIVITAS PAJAK DAERAH PROVINSI DKI JAKARTA

\begin{tabular}{|l|l|l|c|}
\hline $\begin{array}{l}\text { Tahu } \\
\mathrm{n}\end{array}$ & \multicolumn{1}{|c|}{ Target Pajak } & \multicolumn{1}{|c|}{ Realisasi } & $\begin{array}{l}\text { Presenta } \\
\text { se }\end{array}$ \\
\hline 2011 & 13.965 .000 .000$. & $\begin{array}{l}15.221 .249 .152 . \\
690\end{array}$ & $\begin{array}{c}\mathbf{1 0 8 , 9 9} \\
\mathbf{\%}\end{array}$ \\
\hline \multirow{2}{2}{2012} & 16.525 .000 .000$. & 17.721 .493 .016$. & $\mathbf{1 0 7 , 2 4}$ \\
& 000 & 509 & $\mathbf{\%}$ \\
\hline 2013 & 22.618 .000 .000$. & 23.367 .929 .235$. & $\mathbf{1 0 3 , 3 1}$ \\
& 000 & 292 & $\mathbf{\%}$ \\
\hline 2014 & 32.500 .000 .000$. & 27.065 .755 .895$. & $\mathbf{8 3 , 4 0} \%$ \\
& 000 & 364 & \\
\hline \multicolumn{2}{|l|}{ Rata-Rata } & $\mathbf{1 0 0 , 7 3 5}$ \\
\hline
\end{tabular}

Sumber Data: Dinas Pelayanan Pajak Abdul Muis (data diolah)

Bedasarkan hasil analisa diatas, efektifitas pajak daerah mengalami penurunan di tahun 2014 yang hanya mencapai presentase $83,28 \%$ dibawah target pemerintah namun tingkat efektifitas masih dalam kriteria yang efektif. 
Secara umum kinerja belanja Pemerintah Provinsi DKI Jakarta selama tahun 2011-2014 dikatakan cukup efisien dengan presentase antara $80 \%$ - 90\% dan tidak ada realisasi belanja yang melebihi target yang ditetapkan, namun di tahun 2014 realisasi belanja daerah tidak dilakukan secara efektif. Dikatakan dalam Liputan6 (2015) hal tersebut dikarenakan pemerintah daerah sedang melakukan penghematan anggaran.

Apabila dilihat secara keseluruhan besarnya kontribusi total seluruh pajak daerah tahun 2011-2014 dinilai sangat efektif karena presentase yang didapat diatas $100 \%$ dari target yang ditentukan meskipun di tahun 2014 presentase mengalami penurunan namun masih dalam kategori efektif. Namun apabila dilihat dari masing masing pajak daerah yang dipungut, masih ada pajak daerah yang memberikan kontribusi dibawah $100 \%$ yaitu pajak air tanah yang tiap tahunnya presentase penerimaan pajaknya selalu tidak melebihi $80 \%$ yang menurut Mahmudi kurang efektif, serta pajak reklame yang turun drastis penerimaannya di tahun 2014 dikarenakan keluarnya Kebijakan Gubernur DKI Jakarta memberi keringanan pajak reklame 50\% sehingga menyebabkan penurunan penerimaan pajak.

Kinerja pengelolaan keuangan pemerintah provinsi DKI Jakarta bedasarkan rasio kemandirian menunjukan presentase diatas $60 \%$ yang menurut Halim(2002) tingkat kemandirian daerah masih sedang.

\section{Kesimpulan}

Secara keseluruhan kontribusi pajak daerah pada tahun 2011-2014 memberikan peningkatan terhadap Pendapatan Asli Daerah sehingga membantu pemerintah dalam mengkontribusikannya dengan Belanja Daerah. Pertumbuhan kontribusi pajak daerah dalam kurun waktu 2011-2014 mengalami fluktuatif. Hal ini terlihat pada tahun 2012 kontribusi pajak daerah terhadap belanja daerah sedikit menurun namun sampai tahun
2014 persentasi perlahan meningkat. Pertumbuhan kemampuan pajak daerah dalam membiayai belanja daerah terus mengalami peningkatan namun tidak signifikan dikarenakan perekonomian saat ini sedang melemah.

Sebaiknya perlu adanya suatu perencanan ulang dalam mengatur sistem perpajakan yang ada saat ini, dapat dikembangkan dengan sistem online lalu dari perencanaan yang baik tidak akan berpengaruh apabila tidak adanya pengawasan dari pihak pemerintah daerah. peneliti selanjutnya disarankan untuk menambah rasio-rasio analisis agar mendapatkan gambaran yang lebih jelas tentang kinerja pemerintah dalam mengelolah anggaran pendapatan dan belanja daerah.

Penelitian ini hanya dilakukan untuk analisis pajak daerah periode 2011 - 2014 karena adanya keterbatasan pemberian data dari Badan Pengelola Keuangan dan Aset Daerah.

\section{Daftar Pustaka}

Anas, A. (2014). Penerimaan Empat Sektor Pajak Tak Capai Target. Diunduh pada 18 Maret 2016, dari http://www.beritaja karta.com/read /3455/Penerimaan Empat_Sekt or_Pajak_Tak_Capai_Target\#.Vxi_JXr kLIU

Dinas Pelayanan Pajak Provinsi DKI Jakarta. (2012). Himpunan Peraturan Perpajakan Daerah Provinsi DKI Jakarta

Fitriani, F.F. (2015). Pajak Restoran Online, DKI Bagikan 5.555 Alat Pencatat Transaksi. Diunduh pada 18 Maret 2016, dari http://jakarta.b isnis.c om/read/20151229/77/505581/pajakrestoran-online-dki-bagikan-5.555-alatpencatat-transaksi

Halim, Abdul. (2012). Akuntansi Sektor Publik: Akuntansi Keuangan Daerah. Edisi Keempat. Salemba Empat, Jakarta.

Jumene, H. (2015). Tekan Jumlah Kendaraan Pribadi, DKI Naikkan Tarif Pajak Progresif. Diunduh pada 16 Maret 2016, dari http://bisnis.1 
iputan6.com/read/224 6141/tekanjumlah-kendaraan-pribadi-dki-naikkantarif-pajak-progresif

Juwita, N. (2015). Ini Penyebab Pendapatan DKI Menurun. Diunduh pada 18 Maret 2016, dari http://jakarta.bisnis.com/read/20150917 177/473178/ini-penyebab-pen dapatandki-menurun

Kompas. (2015, Agustus 22). Harga Tanah Bergerak Liar, p.1.

Kompasiana. (2015, Juni 24). Tarif PBB Turun 90\%, Kenapa?. Diunduh pada 18 Maret 2016 , dari http://www.kompasiana.com/r yanmintaraga/ tarif-pbb-turun-90-ken apa_5 52b92bf6ea834b51c8b458c

LKP Daerah Provinsi DKI Jakarta Tahun Anggaran 2011 Audited

LKP Daerah Provinsi DKI Jakarta Tahun Anggaran 2012 Audited

LKP Daerah Provinsi DKI Jakarta Tahun Anggaran 2013 Audited

LKP Daerah Provinsi DKI Jakarta Tahun Anggaran 2014 Audited

Mahmudi. (2011). Akuntansi Sektor Publik.Yogyakarta.

Martaon, A. (2015). Ini Penyebab Penerimaan Pajak DKI Jakarta Tidak Tercapai. Diunduh pada 18 Maret 2016, dari http://news.metrotvnews.com/rea d/2015/11/ 19/192699/ini-penyebabpenerimaan-pajak-dki-jakarta-tidaktercapai

Memah, E. (2013). Efektivitas dan Kontribusi Penerimaan Pajak Hotel dan Restoran Terhadap PAD Kota Manado, 871-881.

Nordiawan, D., dan Hertianti, A. (2010).Akuntansi Sektor Publik. Edisi Kedua. Salemba Empat, Jakarta.

Pauwah, S., Saerang, I, Mandey, S., (2014). Analisis Kinerja Keuangan Daerah Pada Pemda Kabupaten Kepulauan Sula Provinsi Maluku Utara, 01-12.

Peraturan Daerah Nomor 2 Tahun 2014 tentang Pajak Rokok

Sugianto. (2008). Pajak dan Retribusi Daerah. Grasindo. Jakarta

Sugiyono. (2014). Metode Penelitian Kuantitatif Kualitatif dan R\&D. Alfabeta. Bandung
Sumenge, A.S (2013). Analisis Efektifitas Dan Efisiensi Pelaksanaan Anggaran Belanja Badan Perencanaan Pembangunan Daerah (BAPPEDA) Minahasa Selatan, 74-81

Statistik Daerah Provinsi DKI Jakarta 2015 